\title{
EFFECTS OF NEURAMINIDASE AND DEOXYRIBONUCLEASE ON THE 3 -ADRENERGIC RECEPTORS IN RAT HEART
}

\author{
Takafumi NAGATOMO and Miyuki SASAKI \\ Department of Pharmacology. Niigata Colloge of Pinarmacy. \\ 5829 Kamishinei-cho. Niigata 950-21. Japan
}

Accepted December 9, 1982

Langer (1) reported that external to the lipid bilayer or unit membrane at the surface of the myocardial cell is the glycocalyx which is composed of two lavers, the surface coat and the external lamina. Both layers contain abundant fixed negatively charged sites which are due in part to the presence of sialic acid in the glycocalyx. Although several investigators have studied the pharmacological specificity of $\beta$-adrenergic receptors in myocardial membranes (sarcolemina) (2-8), it appears that the reproducible determination of the density of $\beta$-adrenergic receptors in the sarcolemma of the myocardium is difficult because of the glycocalyx. The object of this study is to examine the effect of the removal of sialic acid on the , 3-adrenergic receptor assay. In addition, ceoxyribonuclease (DNase), which was found to be beneficial in the isolation of saroolemma from cardiac muscle (9). was also used for the comparison of the effects of these onzymatic treatments on the $\beta$-adrenergic receptors.

${ }^{3} \mathrm{H}(-)$-dihydroatprenolol ( ${ }^{3} \mathrm{H}$ - DHA) (49.4 $\mathrm{Ci} / \mathrm{mmole}$ ) was purchased from New England Nuclear Corp. Neuraminidase (Type $V$. purified from Clostridium perfringens). DNase I (from bovine pancreas) and $\mathrm{dl}$. propranolol were purchased from Sigma Chemical Company. Male Wister rats weighing 200-300 $\mathrm{g}$ were used in this study. After the atria, great vessels, valves, and epicardial fat wero removed, rat ventricles wore suspended in $250 \mathrm{mM}$ sucrose, $10 \mathrm{mM}$ Tris-HCl, pH 7.6. and minced with small scissors. The minced ventricles were homogenized using a Polytron homogenizer for 10 sec twice at setting 8 and filtered through 4 layers of cheese cloth. Three $\mathrm{M} \mathrm{KCl}$ and 250 $\mathrm{mM}$ sodium pyrophosphate were added to adjust the final concentrations to $0.3 \mathrm{M} \mathrm{KCl}$ and $25 \mathrm{mM}$ sodium pyrophosphate to solubilize contractile and other proteins. shaken vigorously, and this suspension was centrifuged at $177.000 \mathrm{~g}$ for $45 \mathrm{~min}$. The pellets obtained were also used to determine the density of $\beta$-adrenoceptors as a control. The pellets were then treated with neuraminidase (0.31 unit/mg protein) in a medium containing $100 \mathrm{mM} \mathrm{KCl}, 10 \mathrm{mM} \mathrm{MgCl}$, $20 \mathrm{mM}$ Tris-maleate. $\mathrm{pH} 7.4$, at $25^{\circ} \mathrm{C}$ for $30 \mathrm{~min}(10)$ or DNase $(60 \mathrm{kunitz}$ unit $/ \mathrm{mg}$ protein) in a medium containing $250 \mathrm{mM}$ sucrose. $10 \mathrm{mM}$ Tris- $\mathrm{HCl}, \mathrm{pH} 7.6$, at $37^{\circ} \mathrm{C}$ for 60 min (9). The suspension treated with these enzymes was centrifuged at $177,000 \mathrm{~g}$ for $45 \mathrm{~min}$, and the pellets were finally resuspended in an "incubation buffer" (75 $\mathrm{mM}$ Tris- $\mathrm{HCl}, 25 \mathrm{mM} \mathrm{MgCl}, \mathrm{pH} 8.0$ ).

Cardiac $\beta$-receptor assays were carried out in cuplicate with ${ }^{3} \mathrm{H}$-DHA in the presence (non-specific) and absence (total) of $5 / \mathrm{MM}$ dl-propranolol. For $3 \mathrm{H}$-DHA binding. $0.5 \mathrm{ml}$ of membrane suspension (0.4-0.6 $\mathrm{mg}$ protein) and different concontrations of ${ }^{3} \mathrm{H}$ DHA were incubated with shaking for $20 \mathrm{~min}$ 
at $23^{\circ} \mathrm{C}$ in a total volume of $1 \mathrm{ml}$ containing $60 \mathrm{mM}$ Tris- $\mathrm{HCl}, \mathrm{pH} 8.0$, and $20 \mathrm{~m} \mathrm{M} \mathrm{MgCl}_{2}$. At the end of the incubation period, the incubation medium was immediately filtered through GF/C glass fiber filters. The filters were washed three times with $5 \mathrm{ml}$ of cold buffer and added to $10 \mathrm{ml}$ of a Triton-toluene based scintillation fluid. The radioactivity of ${ }^{3} \mathrm{H}$-DHA bound mombrane in the absence and presence of d!-propranolol was counted. and the difference in mean values between total and non-specific binding was takon as the specific binding. Specific binding routinely represented approximately 50\% of the total binding in both DNase and neuraminidase treated fractions. Protein determination was done using the method of Lowry et al. (11).

Yields of membrane protein per gram wet weight of cardiac muscles wore $62.8+10.8$ (non-treatment), $53.7 \pm 1.7$ (neuraminidase) and $48.7 \pm 3.6$ (DNase) $\mathrm{mg}$ protein/g tissues. respectivoly. Effocts of neuraminidase and DNase treatment on densities of the $\beta$ adremoceptor binding of rat heart muscle aro shown in Table 1. Neuraminidaso and DNase treatments induced an increase in the number of specific $\beta$-adrenocepter binding sites in rat heart, reflecting the decrease in that of non-specific birdings. This increase was much higher with neuraminidase treatment than in the DNase treated sample.

Figure 1A dopicts the number of total. non-specific or specific binding sites for ${ }^{3} \mathrm{H}$ -
DHA in membranes treated with neuraminidase at different concentrations of ${ }^{3} \mathrm{H}$ D: 1 A. Although the number of specific binding sites for ${ }^{3} \mathrm{H}$-DHA was enhanced with increasing concentrations of $3 H-D H A$, the density of specific binding sites in membranes of cardiac muscle was constant above $5 \mathrm{nM}$ $3 \mathrm{H}$-DHA. The inset in Fig. 1 shows the Scatchard plot of specific ${ }^{3} \mathrm{H}$-DHA binding to mombranes treated with neuraminidase. Values of the dissociation constant $\left(K_{D}\right)$ and the maximum number of binding sites ( $B_{\max }$ ) from the Scatchard analysis were $2.67 \pm 0.53$ $n M$ and $83.5 \pm 8.9$ fmoles $/ \mathrm{mg}$ protein, respec tively. On the other hand, values of $K_{D}$ and $B_{\text {riax }}$ of the membrane fraction treated with DNase were $3.25=0.39 \mathrm{nM}$ and $48.6 \pm 4.01$ fmoles/mg protein, respectively. The $K_{D}$ value in the membrane fraction treated with DNase was not different from that treated with neuraminidase however, a significantly lower $B_{\text {max }}$ was observed $(P<0.05)$. In order to quantitate the modo of saturation, a Hill number of 3 H-DHA binding to cardiac membranes was detormined by the Hill Plot (12). Both of the Hill coefficients equalled to unity.

It is well known that neuraminidase can remove sialic acid from the glycocalyx of the membrane fraction (1.10). Thus as shown in the present study. DNase or neuraminidase treatment results in data indicating that there is a higher density of $\beta$-adrenoceptors

Table 1. Fffects of nouraminidase and deoxyribonuciease troatment on the $\beta$-adrenoceptor binding of rat heart muscle

\begin{tabular}{|c|c|c|c|c|c|}
\hline \multirow[t]{2}{*}{ Treatment } & \multirow{2}{*}{$\begin{array}{c}\text { Yield } \\
(m g \text { protoin/g) }\end{array}$} & \multirow{2}{*}{$\begin{array}{l}\text { Tota' binding } \\
\text { (fmole/mg } \\
\text { protein) }\end{array}$} & \multirow{2}{*}{$\begin{array}{l}\text { Non-specific } \\
\text { binding } \\
\text { (fmole/mg } \\
\text { protein) }\end{array}$} & \multicolumn{2}{|c|}{ Specific binding } \\
\hline & & & & $\begin{array}{l}\text { (fmole/mo } \\
\text { protoin) }\end{array}$ & $\begin{array}{l}\text { (fmole/g } \\
\text { tissue) }\end{array}$ \\
\hline No(8) & 62.8110 .8 & $85.1 \pm 22.2$ & $69.6 \pm 25.1$ & $15.5=4.9$ & 973.4 \\
\hline Neuraminidaso (8) & $53.7 \therefore 1.7$ & $80.1 \pm 3.8$ & $40.7 \pm 3.8$ & $39.4-1.8$ & $2 * 15.8$ \\
\hline DNase (7) & $48.7 \div 3.0$ & $90.7 \pm 3.4$ & $20.7 \div 3$ & $23.0 \pm 2.3$ & $120 . i$ \\
\hline
\end{tabular}

Numbers are tho meanis.E. Numbers in parenthesis show the number of exporinents. The binding

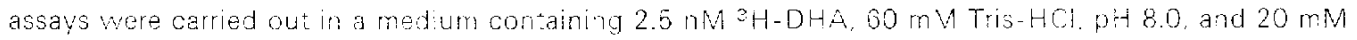
$\mathrm{MgCl}_{2}$ in the prescnce or absence of $5: \mathrm{M}$ dl-propranolol. 

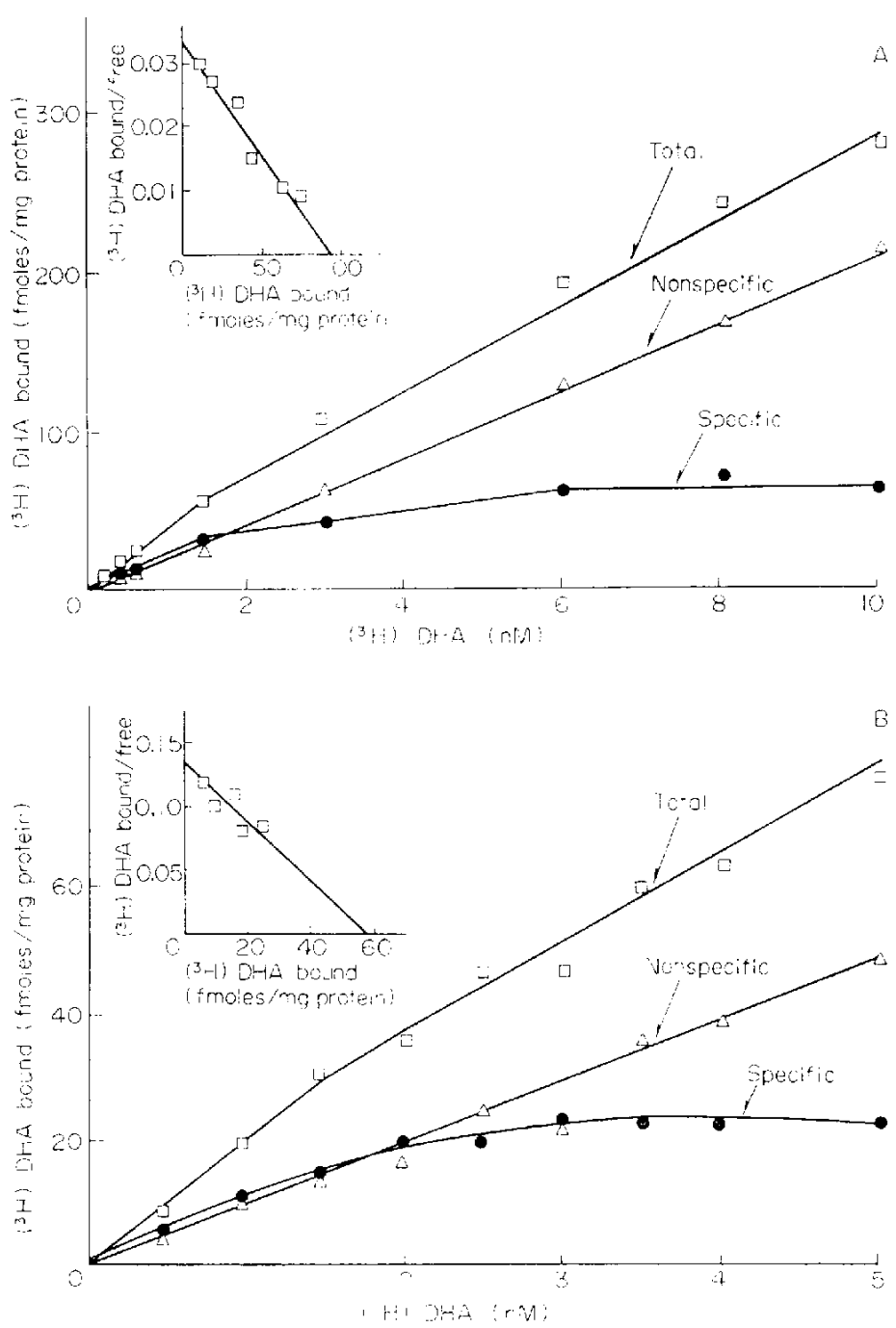

Fig. 1. The binding of ${ }^{3} H-D H A$ to membrane fractions in cardiac muscle troated with neuraminidase (A) or DNase (B). increasing concentration of ${ }^{3} \mathrm{H}-\mathrm{DHA}(0.25-10 \mathrm{nM})$ was incubated in the presence (non-specific) and the absence (total) of $5 \mu \mathrm{M}$ dl-propranclol, and binding to the membrane fraction was assayed. The inset shows a Scatchard plot of specific ${ }^{3} \mathrm{H}-\mathrm{DHA}$ binding to the membrane fraction treated with nouraminidase or DNase in cardiac musclo. Each point represents the mean of 4 experiments, each in duplicate.

than that without the enzyme treatments, and this data is more reproducible than those reported by other investigators. DNase or neuraminidase treatment of cardiac muscle may eliminate some chemica! moleties in the myocardial sarcolemma which interfere with the $\beta$-adrenergic binding.

The $B_{\max }$ value of $\beta$-adrenergic receptors in membrane treated with neuraminidase was two-times higher than that treated with DNase, although the $K_{D}$ values were almost the same. Taeko et al. (10) suggested that reuraminidase treatment was capable of eliminating sialic acids from the glycocalyx. and some of the composed material from the sarcolemmal membrane. As a difference of 
$B_{\max }$ values between DNase and neuraminidase treatment was observed, it appears that the removal of sialic acids from heart membranes may enhance the accessibility of $\beta$-adrenergic receptors.

An improved binding assay using neuraminidase or DNase treatment was developed in order to study $\beta$-adrenergic receptors in the rat heart quantitatively. The use of these methods as a radioligand binding assay may be advantageous in the assessment of $\beta$ adrenergic blockers or for the elucidation of characteristics of $\beta$-adrenergic receptors in cardiac muscle including the role of carbohydrate moieties containing sialic acids in the glycocalyx of the cardiac membrane.

\section{References}

1) Langer, G.A.: The structure and function of the myocardial cell surface. Am. J. Physiol. 235. H461-H468 (1978)

2) Baker, S.P., Boyd, H.M. and Potter, L.T.: Distribution and function of $\beta$-adrenoceptors in different chambers of the canine Heart. Br. J. Pharmacol, 68, 57-63 (1980)

3) Hancock, A.A., DeLean, A.L. and Lefkowitz, R.J.: Quantilative resolution of $\beta$-adrenergic receptor subtype by selective ligand binding: application of a computerized model fitting technique. Mol. Phamacol. 16, 1-9 (1979)

4) Harden, T.K., Wolfe, B.B. and Molinoff, P.B.: Binding of iodinated $\beta$-adrenergic antagonists to proteins derived from rat heart. Mol. Phar- macol. 12, 1-15 (1976)

5) Lefkowitz, R.J., Mukherize, C., Coverstone, $M$. and Caron, M.G.: Stereospecific $\left[{ }^{3} \mathrm{H}\right](-)$ alprenolol binding sites. $\beta$-adrenergic receptors and adeny! cyclase. Biochem. Biophys. Res. Commun. 60, 703-709 (1974)

6) Limas, C. and Limas, C.J.: Reduced number of 5 -adrenergic receptors in the myocardium of spontaneously hypertensive rats. Biochem. Biophys. Res. Commun. 83, 710-714 (1978)

7) Minneman, K.P., Hegstrand, L.R. and Molinoff, P.B.: Simultaneous determination of $\beta-1$ and $\beta$-2-adrenergic receptors in tissues containing both receptor subtypes. Mol. Pharmacol. 16. $34-46(1979)$

8) Williams, L.T., Lefkowitz, R.J., Watanabe, A.M., Hathaway, D.R. and Besch, H.R., Jr: Thyroid hormone regulation of $\beta$-adrenergic receptor number. J. Biol. Chem. 252, 2787-2789 (1977)

9) Tibbits, G.F., Sasaki, M., Ikeda, M., Shimada, K. Tsuruhara, T. and Nagatomo, T.: Characterization of rat myocardial sarcolemma. J. Mol. Call. Cardiol. 13, 1051-1061 (1981)

10) Taeko, S., Daly, M.H., Anand-Srivastava, M.B. and Dhalla, N.S.: Influence of neuraminidase on rat heart sarcolemma. J. Mol. Cell. Cardiol. 12, $211-217(1980)$

11) Lowry, O.H., Rosebrough, N.J., Farr, A.L. and Randal!, R.J.: Protein measurement with the Folin phenol reagent. J. Biol. Chem. 193, 265275(1951)

12) Hill, A.V.: The mode of action of nicotine and curare, determined by the form of the contraction curve and the method of temperature coefficients. J. Physiol. (Lond.) 39, 361-373 (1909) 